\title{
Carbonylative Coupling of 4,4'-Diiodobiphenyl Catalyzed by Pd(NHC) Complex
}

\author{
Do-Hun Lee ${ }^{1^{*}}$, Jung-Tai Hahn², Dai-Il Jung ${ }^{{ }^{*}}$ \\ ${ }^{1}$ Department of Chemistry, Dong-A University, Busan, South Korea \\ ${ }^{2}$ Department of Beautycare, Youngdong University, Youngdong, South Korea \\ Email: *dohlee@dau.ac.kr,dijung@dau.ac.kr
}

Received September 22, 2012; revised November 3, 2012; accepted November 15, 2012

\begin{abstract}
To develop a luminescent material with high color purity, luminous efficiency, and stability, we synthesized diketone by carbonylative Suzuki coupling in the presence of $\mathrm{Pd}(\mathrm{NHC})$ complex as the catalyst. Carbonylative coupling of 4,4'-diiodobiphenyl and phenylboronic acid was investigated to study in detail the catalytic ability of the Pd(NHC) complex. Reactions were carried out using both $\mathrm{CO}$ and metal carbonyls. Bis-(1,3-dihydro-1,3-dimethyl-2H-imidazol2-ylidene) diiodo palladium was used as the catalytic complex. Reaction products biphenyl-4,4'-diylbis (phenylmethanone) 3 and (4'-iodobiphenyl-4-yl)(phenyl) methanone 4 were obtained as a result of CO insertion into the palladium(II)-aryl bond. However, when pyridine-4-yl boronic acid was used in place of phenylboronic acid as the starting reagent, synthetic reaction yielding 3 and 4 were found not to occur.
\end{abstract}

Keywords: Carbonylative Coupling; Metal Carbonyl; Pd(NHC) Complex; 4,4'-Diiodobiphenyl; Phenylboronic Acid

\section{Introduction}

Aryl ketones and flavanoids are common scaffolds in many natural products and biologically active small molecules [1-7]. A carbonylative coupling method for the synthesis of aryl compounds with $\mathrm{CO}$ was pioneered by Heck [8-11]. This method is one of the most efficient and direct routes to synthesize aryl ketones as it forms tow carbon-carbon bonds in a single step, in contrast to the conventional method of introducing ketone functional group in a stepwise fashion. Carbonylative coupling has since been further developed to synthesize a range of carbon nucleophiles [12], including those of tin [13-17], copper [18-22], boron [23-25], zinc [26], aluminum [27], magnesium [28], and silicon [29-31]. Our purpose is to synthesize a new distyryl biphenyl arylene (DBA) derivative as a blue-emitting material. To develop such a luminescent material with high color purity, luminous efficiency, and stability, first of all, we synthesized diketone with $\mathrm{Pd}(\mathrm{NHC})$ complex as a catalyst under a balloon of $\mathrm{CO}$ or metal carbonyl.

During the course of an on-going synthetic project for preparing aryl ketones, we decided to evaluate the applicability of $\mathrm{N}$-heterocyclic carbene (NHC) ligands. NHC ligands have gained popularity in metal-catalyzed crosscoupling reactions for several reasons [32-35]: 1) the

${ }^{*}$ Corresponding authors. steric bulk that they introduce around the metal center facilitates reductive elimination; 2) their strong $\sigma$-donating character enables facile oxidative addition; and 3) their greater stability at elevated temperatures relative to phosphineligands enables their use under a broader range of reaction conditions. Carbonylative Suzuki coupling using the synthesized NHC-Pd complex was carried out under a balloon of $\mathrm{CO}$ or metal carbonyls. To study the scope of the process, the reaction conditions were optimizied for the cross-coupling of 4,4'-diiodobiphenyl and phenylboronic acid with $\mathrm{N}$-heterocyclic carbene (NHC) ligand under a balloon (1 atm) of CO or metal carbonyls. 4,4'-diiodobiphenyl 1) and phenylboronic acid 2) were reacted under CO (1 bar, a balloon) atmosphere in the presence of the $\mathrm{Pd}(\mathrm{NHC})$ complex catalyst formed in situ $[36,37]$.

\section{Experimental}

\subsection{Carbonylative Coupling Reaction under Carbon Monoxide}

In a typical reaction, $\mathrm{Pd}(\mathrm{NHC})$ complex $\left(2 \times 10^{-3} \mathrm{~g}, 5 \times\right.$ $10^{-2} \mathrm{~mol}$ ) was dissolved in $15 \mathrm{~mL}$ anisole under $\mathrm{N}_{2}$ gas. After the formation of a pale brown homogeneous solution, phenylboronic acid $\left(0.112 \mathrm{~g}, 1 \times 10^{-3} \mathrm{~mol}\right), 4,4^{\prime}-$ diiodobiphenyl $\left(0.203 \mathrm{~g}, 5 \times 10^{-4} \mathrm{~mol}\right)$, and potassium carbonate $\left(0.425 \mathrm{~g}, 1.5 \times 10^{-3} \mathrm{~mol}\right)$ were added. The at- 
mosphere was changed to carbon monoxide and the reaction mixture was kept at $80^{\circ} \mathrm{C}$ for $24 \mathrm{~h}$. After elimination of $\mathrm{Pd}(\mathrm{NHC})$ complex by filteration, the reaction mixture was diluted water $(10 \mathrm{~mL})$ and $\mathrm{CH}_{2} \mathrm{Cl}_{2}(20 \mathrm{~mL})$. The neutralized solution was extracted with $\mathrm{CH}_{2} \mathrm{Cl}_{2}$. The organic layer was dried $\left(\mathrm{Na}_{2} \mathrm{SO}_{4}\right)$, filtered, and concentrated. The reaction mixture was analyzed immediately by GC-MS. The residue was chromatographed on a silica gel (n-hexane:ethylacetate $=20: 1, \mathrm{v} / \mathrm{v})$ yield $3(0.154 \mathrm{~g}$, $42.6 \%)$ and $4\left(4.9 \times 10^{-2} \mathrm{~g}, 12.7 \%\right)$.

\subsection{Carbonylative Coupling Reaction under Metal Carbonyl}

The mixture of 4,4'-diiodobiphenyl (0.203 g, $5 \times 10^{-4}$ $\mathrm{mol})$, phenylboronic acid $\left(0.112 \mathrm{~g}, 1 \times 10^{-3} \mathrm{~mol}\right), \mathrm{K}_{2} \mathrm{CO}_{3}$ $\left(0.425 \mathrm{~g}, 1.5 \times 10^{-3} \mathrm{~mol}\right)$ and Di-(1,3-dihydro-1,3-dimethyl-2H-imidazol-2-ylidene)diiodopalladium $\left(2 \times 10^{-3}\right.$ g, $\left.5 \times 10^{-2} \mathrm{~mol}\right)$ and Molybdenum hexacarbonyl $(9.2 \times$ $10^{-2}$ mol, $0.7 \mathrm{eq}$ ) was stirred in $15 \mathrm{~mL}$ anisole under $\mathrm{N}_{2}$. The reaction mixture was kept at $80^{\circ} \mathrm{C}$ for $24 \mathrm{~h}$. After elimination of $\mathrm{Pd}(\mathrm{NHC})$ complex by filteration, the reaction mixture was diluted water $(10 \mathrm{~mL})$ and $\mathrm{CH}_{2} \mathrm{Cl}_{2}(20$ $\mathrm{mL}$ ). The neutralized solution was extracted with $\mathrm{CH}_{2} \mathrm{Cl}_{2}$. The organic layer was dried $\left(\mathrm{Na}_{2} \mathrm{SO}_{4}\right)$, filtered, and concentrated. The reaction mixture was analyzed immediately by GC-MS. The residue was chromatographed on a silica gel (n-hexane:ethylacetate $=20: 1, \mathrm{v} / \mathrm{v}$ ) yield 3 $(0.189 \mathrm{~g}, 52.3 \%)$ and $4\left(5.2 \times 10^{-2} \mathrm{~g}, 13.5 \%\right)$.

\subsection{Synthesis of Bis-(1,3-dihydro-1,3-dimethyl- 2H-imidazol-2-ylidene) diiodopalladium}

The synthetic scheme for producing bis-(1,3-dihydro-1,3dimethyl-2H-imidazol-2-ylidene) diiodopalladium catalyst is as follows:
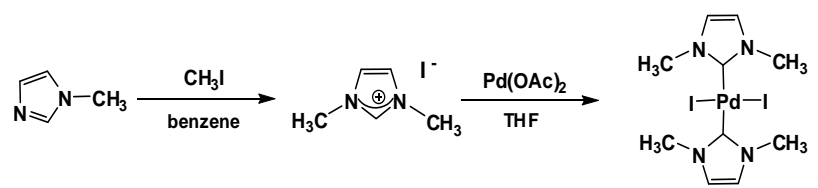

$N, N$ '-dimethyl imidazolium iodide was obtained by the reaction of $N$-methylimidazole with methyl iodide. Following this, reaction of $N, N^{\prime}$-dimethyl imidazolium iodide with palladium acetate resulted in NHC-Pd complex in good yield (72\%).

\section{Results and Discussion}

The desired carbonylative products biphenyl-4,4'-diylbis (phenyl-methanone) 3 and (4'-iodobiphenyl-4-yl)(phenyl) methanone 4 were formed in all cases, irrespective of the reaction conditions.

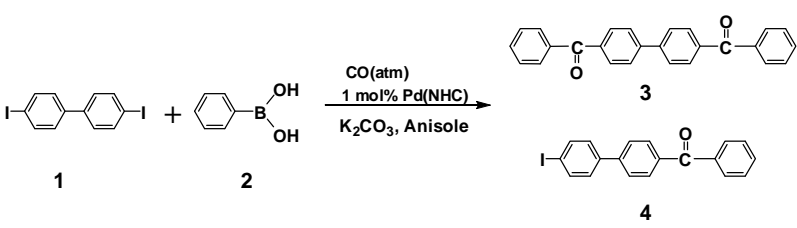

When metal carbonyl [for $\mathrm{Mo}(\mathrm{CO})_{6}: 3=42.6 \%$ and 4 $=12.7 \% ; \mathrm{Mn}_{2}(\mathrm{CO})_{10}: 3=6.6 \%$ and $4=33.1 \% ; \mathrm{Co}_{2}(\mathrm{CO})_{8}$ : $3=48.6 \%$ and $4=11.2 \% ; \mathrm{Fe}_{3}(\mathrm{CO})_{12}: 3=9.9 \%$ and $4=$ $24.8 \% ; \mathrm{Fe}(\mathrm{CO})_{5}: 3=62.5 \%$ and $4=10.6 \%$ ] was used in place of $\mathrm{CO}$, we achieved the same reaction products.

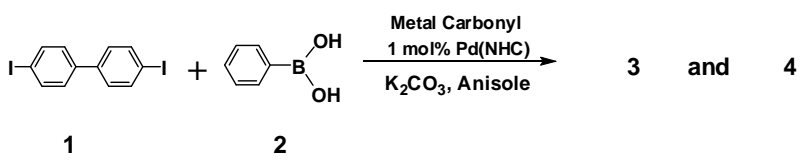

In reactions with $\mathrm{Mn}_{2}(\mathrm{CO})_{10}$ and $\mathrm{Fe}_{3}(\mathrm{CO})_{12}$ as metal carbonyals, yield of 4 was higher then that of 3 . As seen in Table 1, various metal carbonyls were as effective as $\mathrm{CO}$ donors as $\mathrm{CO}$ itself. The plausible mechanism of diketone formation is assumed to be as shown in Scheme 1.

\section{Conclusions}

When metal carbonyl was used in place of $\mathrm{CO}$, we achieved the same reaction products.

We assume that the two reactions needed to obtain 3 require a longer reaction time as 4 is formed as a reaction intermediate. When pyridine-4-ylboronic acid is used in place of phenylboronic acid,<smiles>OB(O)c1ccncc1</smiles>

carbonylative Suzuki coupling under $\mathrm{CO}$ or metal carbonyls $\left[\mathrm{Mo}(\mathrm{CO})_{6}, \mathrm{Mn}_{2}(\mathrm{CO})_{10}, \mathrm{Co}_{2}(\mathrm{CO})_{8}, \mathrm{Fe}_{3}(\mathrm{CO})_{12}\right.$, and $\left.\mathrm{Fe}(\mathrm{CO})_{5}\right]$ is found not to occur. In future, we intend to

Table 1. Carbonylative Suzuki coupling with phenylboronic acid and 4,4'-diiodobiphenyl.

\begin{tabular}{|c|c|c|c|c|c|c|}
\hline \multirow{2}{*}{ Run } & \multirow{2}{*}{ Iodide } & \multirow{2}{*}{$\begin{array}{c}\text { Boronic } \\
\text { acid }\end{array}$} & \multirow{2}{*}{$\mathrm{CO}$} & \multirow{2}{*}{$\begin{array}{c}\text { Reaction } \\
\text { time }(\mathrm{h})\end{array}$} & \multicolumn{2}{|c|}{ Yield $(\%)$} \\
\hline & & & & & 3 & 4 \\
\hline 1 & & & CO (gas) & $24 \mathrm{~h}$ & 42.6 & 12.7 \\
\hline 2 & & & $\mathrm{Mo}(\mathrm{CO})_{6}$ & $24 \mathrm{~h}$ & 52.3 & 13.5 \\
\hline 3 & & & $\mathrm{Mn}_{2}(\mathrm{CO})_{10}$ & $24 \mathrm{~h}$ & 6.6 & 33.1 \\
\hline 4 & & & $\mathrm{Co}_{2}(\mathrm{CO})_{8}$ & $24 \mathrm{~h}$ & 48.6 & 11.2 \\
\hline 5 & & & $\mathrm{Fe}_{3}(\mathrm{CO})_{12}$ & $24 \mathrm{~h}$ & 9.9 & 24.8 \\
\hline 6 & & & $\mathrm{Fe}(\mathrm{CO})_{5}$ & $24 \mathrm{~h}$ & 62.5 & 10.6 \\
\hline
\end{tabular}




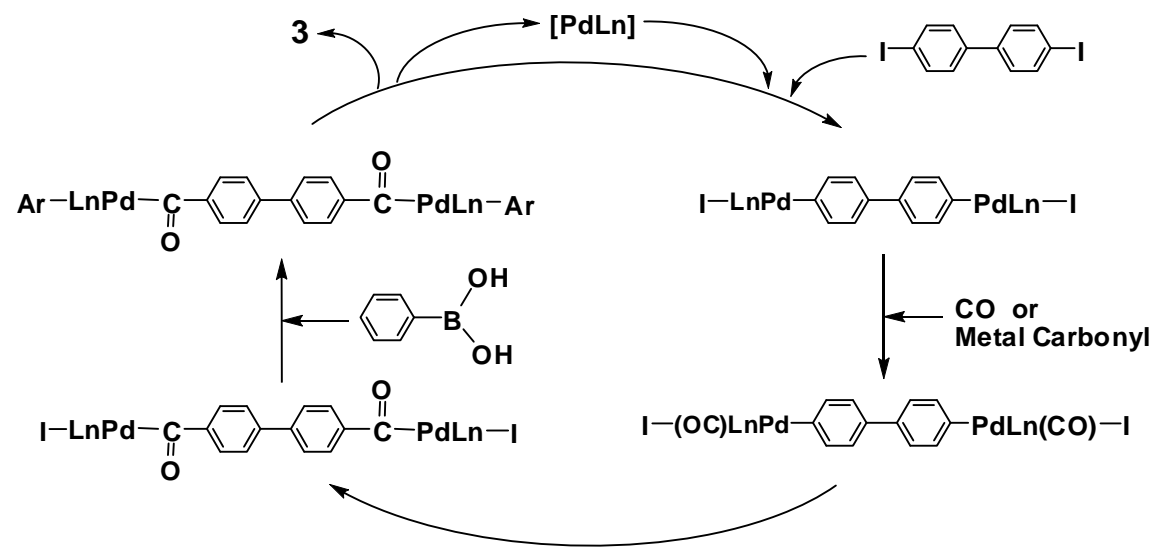

Scheme 1. Simplified catalytic cycle showing the formation of 3.

synthesize various diketones by using heteroaromatic boronic acid to develop a luminescent material.

\section{Acknowledgements}

The work was supported by a grant of Dong-A University (2012).

\section{REFERENCES}

[1] Y. Jiang and P. Tu, "Four New Phenones from the Cortexes of Polygalatenuifolia," Chemical \& Pharmaceutical Bulletin, Vol. 53, No. 9, 2005, pp. 1164-1166. doi:10.1248/cpb.53.1164

[2] Nilar, L.-H. D. Nguyen, G. Venkatraman, K.-Y. Sim and L. J. Harrison, "Xanthones and Benzophenones from Garciniagriffithii and Garcinia mangostana," Phytochemistry, Vol. 66, No. 14, 2005, pp. 1718-1723. doi:10.1016/j.phytochem.2005.04.032

[3] J. W. Lampe, C. K. Biggers, J. M. Defauw, R. J. Foglesong, S. E. Hall, J. M. Heerding, S. P. Hollinshead, H. Hu, P. F. Hughes, G. E. Jagdmann Jr., M. G. Johnson, Y.-S. Lai, C. T. Lowden, M. P. Lynch, J. S. Mendoza, M. M. Murphy, J. W. Wilson, L. M. Ballas, K. Carter, J. W. Darges, J. E. Davis, F. R. Hubbard and M. L. Stamper, "Synthesis and Protein Kinase Inhibitory Activity of Balanol Analogues with Modified Benzophenone Subunits," Journal of Medicinal Chemistry, Vol. 45, No. 12, 2002, pp. 2624-2643. doi:10.1021/jm020018f

[4] S. Rancon, A. Chaboud, N. Darbour, G. Comte, C. Bayet, P.-N. Simon, J. Raymond, A. Di Pietro, P. Cabalion and D. Barron, "Natural and Synthetic Benzophenones: Interaction with the Cytosolic Binding Domain of P-Glycoprotein," Phytochemistry, Vol. 57, No. 4, 2001, pp. 553-557. doi:10.1016/S0031-9422(01)00120-0

[5] H. Ito, E. Nishitani, T. Konoshima, M. Takasaki, M. Kozuka and T. Yoshida, "Flavonoid and Benzophenone Glycosides from Coleogyne ramosissima," Phytochemistry, Vol. 54, No. 7, 2000, pp. 695-700.

[6] J.-C. Li and T. Nohara, "Benzophenone C-Glucosides from Polygala Telephioides," Chemical \& Pharmaceutical Bulletin, Vol. 48, No. 9, 2000, pp. 1354-1355. doi: $10.1248 / \mathrm{cpb} .48 .1354$

[7] B. M. O'Keefe, N. Simmons and S. F. Martin, "Carbonylative Cross-Coupling of ortho-Disubstituted Aryl Io dides. Convenient Synthesis of Sterically Hindered Aryl Ketones," Organic Letters, Vol. 10, No. 22, 2008, pp. 5301-5304. doi:10.1021/ol802202j

[8] R. F. Heck, "A Synthesis of Diaryl Ketones from Arylmercuric Salts," Journal of the American Chemical Society, Vol. 90, No. 20, 1968, pp. 5546-5548. doi: $10.1021 / \mathrm{ja} 01022 \mathrm{a} 040$

[9] A. Schoenberg, I. Bartoletti and R. F. Heck, "PalladiumCatalyzed Carboalkoxylation of Aryl, Benzyl, and Vinylic Halides," Journal of Organic Chemistry, Vol. 39, No. 23, 1974, pp. 3318-3326. doi:10.1021/jo00937a003

[10] A. Schoenberg and R. F. Heck, "Palladium-Catalyzed Amidation of Aryl, Heterocyclic, and Vinylic Halides," Journal of Organic Chemistry, Vol. 39, No. 23, 1974, pp. 3327-3331. doi:10.1021/jo00937a004

[11] J.-J. Brunetand R. Chauvin, "Synthesis of Diarylketones through Carbonylative Coupling," Chemical Society Reviews, Vol. 24, No. 2, 1995, p. 89. doi:10.1039/cs9952400089

[12] Y. Tamaru and M. Kimura, "Reactions of Acylpalladium Derivatives with Organometals and Related Carbon Nucleophiles," Handbook of Organopalladium Chemistry for Organic Synthesis, Vol. 2, 2002, pp. 2425-2454.

[13] V. Farina, V. Krishnamurthy and W. J. Scott, "Stille Reaction," Organic Reactions, Vol. 50, No. 1, 1997, pp. 1652.

[14] S.-K. Kang, T. Yamaguchi, T.-H. Kim and P.-S. Ho, "Copper-Catalyzed Cross-Coupling and Carbonylative Cross-Coupling of Organostannanes and Organoboranes with Hypervalent Iodine Compounds," Journal of Organic Chemistry, Vol. 61, No. 26, 1996, pp. 9082-9083. doi:10.1021/j0962033w

[15] A. M. Echavarren and J. K. Stille, "Palladium-Catalyzed Coupling of Vinyl Epoxides with Organostannanes," Journal of the American Chemical Society, Vol. 110, No. 12, 1988, pp. 4039-4041. doi:10.1021/ja00220a054

[16] J. K. Stille, "The Palladium-Catalyzed Cross-Coupling Reaction of Organotin Reagents with Organic Electro- 
philes," Angewandte Chemie International Edition English, Vol. 25, No. 6, 1986, pp. 508-524.

doi:10.1002/anie.198605081

[17] M. Tanaka, "Unsymmetrical Ketone Synthesis from Organic Halides, Carbon Monoxide, and Organotin Compounds Catalyzed by a Palladium Complex," Tetrahdron Letters, Vol. 20, No. 28, 1979, pp. 2601-2602. doi:10.1016/S0040-4039(01)86360-7

[18] V. Sans, A. M. Trzeciak, S. Luis and J. J. Ziolkowski, "PdCl2( $\mathrm{P}(\mathrm{OPh})(3))(2)$ Catalyzed Coupling and Carbonylative Coupling of Phenylacetylenes with Aryl Iodides in Organic Solvents and in Ionic Liquids," Catalysis Letters, Vol. 109, No. 1-2, 2006, pp. 37-41. doi:10.1007/s10562-006-0053-7

[19] P. J. Tambade, Y. P. Patil, N. S. Nandurkar and B. M. Bhanage, "Copper-Catalyzed, Palladium-Free Carbonylative Sonogashira Coupling Reaction of Aliphatic and Aromatic Alkynes with Iodoaryls," Synle, No. 6, 2008, pp. 886-888.

[20] N. Haddad, J. Tan and V. Farina, "Convergent Synthesis of the Quinolone Substructure of BILN 2061 via Carbonylative Sonogashira Coupling/Cyclization," Journal of Organic Chemistry, Vol. 71, No. 13, 2006, pp. 5031-5034. doi:10.1021/jo060556q

[21] M. S. M. Ahmed and A. Mori, "Carbonylative Sonogashira Coupling of Terminal Alkynes with Aqueous Ammonia," Organic Letters, Vol. 5, No. 17, 2003, pp. 30573060. doi:10.1021/o1035007a

[22] S. Torii, H. Okomoto, L. H. Xu, M. Sadakane, M. V. Shostakovsky, A. B Ponomaryov and V. N. Kalinin, "Syntheses of Chromones and Quinolones via Pd-Catalyzed Carbonylation of O-Iodophenols and Anilines in the Presence of Acetylenes," Tetrahdron, Vol. 49, No. 31, 1993, pp. 6773-6784. doi:10.1016/S0040-4020(01)80421-X

[23] T. Ohe, K. Ohe, S. Uemura and N. Sugita, "Palladium(0)-Catalyzed Carbonylation of Alkenyl- and Arylborates and Boronic Acids with Carbon Monoxide," Journal of Organometallic Chemistry, Vol. 344, No. 1, 1988, pp. c5c7. doi:10.1016/0022-328X(88)80220-1

[24] T. Ishiyama, H. Kizaki, T. Hayashi, A. Suzuki and N. Miyaura, "Palladium-Catalyzed Carbonylative CrossCoupling Reaction of Arylboronic Acids with Aryl Electrophiles: Synthesis of Biaryl Ketones," Journal of Organic Chemistry, Vol. 63, No. 14, 1998, pp. 4726-4731. doi:10.1021/jo980417b

[25] M. B. Andrus, Y. Ma, Y. Zang and C. Song, "Palladium-Imidazolium-Catalyzed Carbonylative Coupling of Aryl Diazonium Ions and Aryl Boronic Acids," Tetrahedron Letters, Vol. 43, No. 50, 2002, pp. 9137-9140. doi:10.1016/S0040-4039(02)02186-X

[26] Q. Wang and C. Chen, "Nickel-Catalyzed Carbonylative Negishi Cross-Coupling Reactions," Tetrahedron Letters, Vol. 49, No. 18, 2008, pp. 2916-2921. doi:10.1016/j.tetlet.2008.03.035

[27] N. A. Bumagin, A. B. Ponomaryov and I. P. Beletskya, "Ketone Synthesis via Palladium-Catalyzed Carbonylation of Organoaluminium Compounds," Tetrahedron Letters, Vol. 26, No. 39, 1985, pp. 4819-4822.

\section{doi:10.1016/S0040-4039(00)94960-8}

[28] T. Yamamoto, T. Kohara and A. Yamamoto, "Selective Formation of Ketone, Diketone and Aldehyde by the Co Insertion into Nickel-Alkyl Bonds of Dialkylnickel Complexes. A Novel Nickel-Catalyzed Syntheses of Ketones and Tertiary Alcohols from Grignard Reagents, Aryl Halides, and Carbon Monoxide," Chemistry Letters, Vol. 5, No. 11, 1976, pp. 1217-1220. doi:10.1246/cl.1976.1217

[29] Y. Hatanaka, S. Fukushima and T. Hiyama, "Carbonylative Coupling Reaction of Organofluorosilanes with Organic Halides Promoted by Fluoride Ion and Palldium Catalyst," Tetrahedron, Vol. 48, No. 11, 1992, pp. 21132126. doi:10.1016/S0040-4020(01)88878-5

[30] Y. Hatanaka and T. Hiyama, "Highly Selective CrossCoupling Reactions of Organosilicon Compounds Mediated by Fluoride Ion and a Palladium Catalyst," Synlett, Vol. 1991, No. 12, 1991, pp. 845-853. doi:10.1055/s-1991-20899

[31] Y. Hatanaka and T. Hiyama, "Palladium-Catalyzed Carbonylative Coupling of Arylfluorosilanes with Aryl Iodides. A Convenient Synthesis of Diaryl Ketones," Chemistry Letters, Vol. 18, No. 11, 1989, pp. 2049-2052. doi:10.1246/cl.1989.2049

[32] E. A. B. Kantchev, C. J. O'Brien and M. G. Organ, "Palladium Complexes of N-Heterocyclic Carbenes as Catalysts for Cross-Coupling Reactions-A Synthetic Chemist's Perspective," Angewandte Chemie International Edition, Vol. 46, No. 16, 2007, pp. 2768-2813.

doi: $10.1002 /$ anie. 200601663

[33] K. J. Covell and D. S. McGuinness, "Redox Processes Involving Hydrocarbylmetal ( $N$-Heterocyclic Carbene) Complexes and Associated Imidazolium Salts: Ramifications for Catalysis," Coordination Chemistry Reviews, Vol. 248, No. 7-8, 2004, pp. 671-681. doi:10.1016/j.ccr.2004.02.006

[34] W. A. Herrmann, "N-Heterocyclic Carbenes: A New Concept in Organometallic Catalysis," Angewandte Chemie International Edition, Vol. 41, No. 8, 2002, pp. 12901309.

doi:10.1002/1521-3773(20020415)41:8<1290::AID-ANI E1290>3.0.CO;2-Y

[35] A. C. Hillier, G. A. Grasa, M. S. Viciu, H. M. Lee, C. Yang and S. P. Nolan, "Catalytic Cross-Coupling Reactions Mediated by Palladium/Nucleophilic Carbene Systems," Journal of Organometallic Chemistry, Vol. 653, No. 1-2, 2002, pp. 69-82. doi:10.1016/S0022-328X(02)01154-3

[36] P. Andrea, P. Gabor, P. Zoltan and K. Laszlo, "Carbonylative and Direct Suzuki-Miyaura Cross-Coupling Reactions with 1-Iodo-Cyclohexene," Journal of Molecular Catalysis, Vol. 255, No. 1-2, 2006, pp. 97-102.

doi:10.1016/j.molcata.2006.03.070

[37] L. M. Daniela, M. A. Heiddyand and C. S. A. Lucia, "Microwave-Assisted Suzuki Reaction Catalyzed by $\operatorname{Pd}(0)$ PVP Nanoparticles," Tetrahedron Letters, Vol. 51, No. 52, 2010, pp. 6814-6817. doi:10.1016/j.tetlet.2010.09.145 